\title{
INTER-RELATIONSHIP BETWEEN PROFITABILITY, GROWTH AND SIZE: CASE OF TURKEY
}

DOI: 10.17261/Pressacademia.2015424534

\section{Kartal Demirgunes', Gulbahar Ucler ${ }^{2}$}

${ }^{1}$ Ahi Evran University, Kırşehir, Turkey. Email: kartal.demirgunes@ahieran.edu.tr

${ }^{2}$ Ahi Evran University, Kırşehir, Turkey. Email: gulbaharucler@hotmail.com

\section{Keywords}

Profitability, Growth,

Size, Multiple structural breaks, Bootstrap causality

\begin{abstract}
This study aims to analyze inter-relationship between firm profitability, growth and size by using quarterly data of Turkish manufacturing industry consisting of Borsa Istanbul (BIST) listed manufacturing firms covering 1991.Q2-2014.Q4. In the study, to test the stationarity of series and the co-integration relationship between them, unit root test of Carrioni-iSilvestre et. al. (2009) and co-integration test of Maki (2012) are used, respectively. Co-integration coefficients are estimated by means of Stock and Watson (1993)'s dynamic ordinary least squares (DOLS) method. Finally, causal relationships between the series are tested by Hacker and Hatemi-J (2012) bootstrap causality test. Structural break dates estimated point out dramatic turning points in Turkish economy. Maki (2012) test results show that the series are co-integrated in the long-run. Long-run parameters estimated by DOLS method posit a significantly negative relationship between profitability and size. Causality test results indicate the existence of one-way causality from size to profitability.
\end{abstract}

\section{INTRODUCTION}

The inter-relationship between firm profitability, growth and size has attracted massive research interest among academic researchers and industry practitioners for several decades (Goddard et. al., 2006; Brännback et. al., 2009). However, related empirical findings show inconsistency (See Coad, 2007, 2009; Davidsson et. al., 2009; Steffens et. al., 2009). The explanation of this inconsistency can be that though it is generally presumed that profitability and growth (and consequently, size) influence each other, they may not be necessarily connected. Therefore the impact and direction of the inter-relationship between them remain ambiguous. Greiner (1972) tries to explain this ambiguity with several arguments. According to him, excessive and/or rapid growth may contribute to a breakdown of informal relationships established over time in firms causing increases in formality in relationships, profitability may be negatively affected. However, excessive and/or rapid growth may also result in greater profitability as an outcome of increased motivation among employees expecting additional gains in future due to this growth. Beyond these managerial explanations, the ambiguity may also be related with 
econometric issues. Due to endogeneity, it is difficult to capture a clear causality and direction between profitability, growth and size. Moreover, incorporation of profitability and growth time lags into the econometric models complicates the endogenous relationship between them due to unknown influences of different time lags.

This study aims to shed light on the inter-relationship between firm profitability, growth and size intentionally focusing on econometric issues, rather than managerial implications. Throughout this aim, advanced econometric methods are performed to estimate the mentioned inter-relationship on a sample of Turkish manufacturing industry (consisting of Borsa Istanbul (BIST) listed manufacturing firms) for the period of 1991.Q2-2014Q4. In the following section of the study, literature review is presented. Then methodology and empirical results are given. Finally, in the Conclusion, findings are discussed, limitations of the study and suggestions for further studies are presented.

\section{LITERATURE REVIEW}

There exist a very comprehensive literature on the inter-relationship between profitability, growth and size. However, while the majority of studies focus on dual relationships between these variables such as profitability-growth, profitability-size or growth-size in a limited framework; a few of them attempt to undertake the entire relationship in depth. Empirically considering both profitability-growth and profitabilitysize inter-relationships with their causalities, this study is one of the latter. As it is widely assumed that profitability and growth are inter-related, the literature should be discussed from two different perspectives such as (1) the effect of growth on profitability, and (2) the effect of profitability on growth. Concerning the first perspective, there exists several theories claiming that growth positively affects profitability such as Kaldor-Verdoorn Law suggested by Verdoorn (1949) and Kaldor (1966). According to this law, (firm) growth increases the productivity of a firm and this increase triggers sales' growth and consequently profitability. However, this notion conflicts with the theory of diseconomies of scale, an economic concept in which economies of scale -sustaining that larger firms with relatively high growth rates may benefit from cost advantages due to their economies of scale and in turn enhanced profitability- no longer function. Beyond these theories, related empirical studies also indicate similar inconsistent findings. While findings from studies of Capon et. al. (1990), Chandler and Jansen (1992), Mendelson (2000), Cowling (2004), Serrasquerio et. al. (2007), Asimakopoulous et. al. (2009), Serrasquerio (2009) and Jan and Park (2011) indicate positive effect of growth on profitability; Reid (1995)'s, Roper (1999)'s, Gschwandtner (2005)'s and Nakano and Kim (2011)'s findings are opposite to them.

From the second perspective, some prior studies like Alchian (1950)'s theoretical article, financing constraints-based hypotheses, and pecking order theory firstly suggested by Donaldson (1961), then modified and popularized by Myers (1984) and Myers and Majluf (1984) have placed emphasis on the positive effect of profitability on growth. In contrast, some theories have been put forth opposing this effect such as the managerial growth maximization hypothesis under market competition (Mueller, 1972). This theory asserts that firm's primary managerial objective is growth maximization -rather than profit maximization-, and this objective may sometimes cause decreases in profit rates as a 
result of competitive relationship between profitability and growth. In the scope of empirical studies, inconsistent research findings are also seen. Robson and Bennett (2000), Cox et. al. (2002), Liu and Hsu (2006), Coad (2007) and Bottazzi et. al. (2008) express that profitability affects firm growth positively. However, an opposite effect has been observed in studies of Capon et. al. (1990), Markman and Gartner (2002) and Coad (2010).

Firm size as a proxy of firm's resources is one of the other main determinants of profitability due to theory of economies of scale positing that for bigger firms, manufacturing costs are relatively low compared to the smaller ones. According to this theory, the relationship between profitability and size is expected to be positive. However, opposite of economies of scale, i.e. diseconomies of scale theory predicts that efficiency lessens in firms expanding beyond their optimum scales as a result of several diseconomies including poor communication, co-ordination, $x$-inefficiency, low motivation and agency problems. In such circumstances, the expected direction of the relationship may turn out to negative. Theoretical and empirical evidence concerning the relationship between profitability and size has also attracted massive interest. While in the pioneering studies of McConnell (1946), Alexander (1949), Haines (1970) and Shepherd (1972), a weak or negative relationship or none at all have been obtained; Hall and Weiss (1967), and Gale (1972) have found positive relationship between profitability and size. Following them, mixed empirical results have been obtained from mainly cross-sectional and time series studies. Briefly concluding that larger firms have tendency to have higher rates of profitability, and therefore supporting the theory of economies of scale; Fiegenbaum and Karnani (1991), Gschwandtner (2005), Özgülbaş et. al. (2006), Wu (2006), Jonsson (2007), Akbaş and Karaduman (2012), Mule et. al. (2015) find that size has significantly positive effect on profitability. On the contrary, findings of Amato and Burson (2007), BeckerBlease et. al. (2010) and Khatap et. al. (2011) indicate statistically negative relationship between profitability and size.

\section{DATA, VARIABLES and THE MODEL}

The data of the study covers 1991.Q2-2014.Q4 for the manufacturing industry (consisting of Borsa Istanbul (BIST) listed manufacturing firms) in Turkey. As mentioned before, the primary aim of the study is to analyze possible relationship between profitability and growth. Additionally, size -as an alternative possible determinant of profitability- is also undertaken in order to check the robustness of the profitability-growth relationship and to enhance the empirical analysis. Therefore, three key variables are included in two different models: profitability as dependent variable in both models, and growth and size as independent variables in each model. These three variables can be measured in different ways due to the aim and context of the studies involved. For instance, while many researchers such as Amato and Wilder (1985), Roquebert et. al. (1996), McGahan and Porter (1997), Glancey (1998), Mauri and Michael (1998), Claver et. al. (2002), Fitzsimmons et. al. (2005), Asimakopoulous et. al. (2009), Davidsson et. al. (2009), Narware (2010), Vijayakumar and Devi (2011), Delmar et. al. (2013), and Li and Wang (2014) have used return on assets (ROA); some such as Hall and Weiss (1967), Ebaid (2009), Ferati and Ejupi (2012), Velnampy and Niresh (2012), and Bokhari and Khan (2013) 
have used return on equity (ROE) as profitability variable. Here, it can be emphasized that $R O E$ has mostly been used in studies related with (especially in financial) service industries. Additionally, less often than $R O A$ and $R O E$, some other profitability variables such as return on sales (ROS) (see, for instance, Fitzsimmons et. al., 2005; Jang and Park, 2011; Vijayakumar and Devi, 2011), and earnings before interest and taxes (EBIT) (see, for instance, Kwoka and Ravenscraft, 1986; Brännback et. al., 2009; Fareed et. al., 2014) have also been used in related studies. In this study, the most generally employed profitability variable; i.e., return on assets is used as the dependent variable, as it gives a quick indication of the capital intensity and assets utilization depending on the industry, and overcomes variations based on size in terms of total profits. Besides, use of ROA rather than $R O E$ and any other profitability variables shows consistency with the data.

As in most of related studies (Delmar, 1997; Weinzimmer et. al., 1998; Coad, 2007; Short et. al., 2009; Serrasquerio, 2009; Bottazzi et. al., 2010; Jang and Park, 2011), the growth variable focused on this study is sales' growth. It is relatively easy to obtain sales' growth data from financial statements. As an important indicator reflecting both short-term and long-term changes in sales capacity of the industry, sales' growth is also favored by entrepreneurs themselves (Barkham et. al., 1996). The study by Shepherd and Wiklund (2009) delving into the relationships between various growth variables such as growth in (1) sales, (2) employees, (3) profit, (4) assets, and (5) equity indicates that in many situations sales' growth is the most appropriate variable for growth.

Size is the other independent variable of the model. There are several size variables used by researchers in their studies such as total assets (see, for instance, Friend and Lang, 1988; Anderson and Makhija, 1999; Frank and Goyal, 2003; Dalbor et. al., 2004; Deesomsak, 2004; Padron et. al., 2005; Zeitun and Tian, 2007; Saliha and Abdessatar, 2011; Doğan, 2013), total sales (see, for instance, Titman and Wessels, 1988; Rajan and Zingales, 1995; Wiwattanakantang, 1999; Booth et. al., 2001; Huang and Song, 2006; Serrasquerio and Nunes, 2008), and number of employees (see, for instance, Bonaccorsi, 1992; Archarungroj and Hoshino, 1998; Jonsson, 2007). In this study, size variable is represented by total assets due to the fact that it is the most appropriate variable to epitomize the size of activities. It is measured as the natural logarithm of total assets with the aim of controlling a possible non-linearity in the data, and the consequent problem of heteroscedasticity (Sogorb and Lopez, 2003). Definitions and calculations about the variables of the study are summarized in Table 1.

Table 1.: Definitions of Variables

\begin{tabular}{|l|l|l|}
\hline Variable & Calculation & Symbol \\
\hline Profitability (Return On Assets) & Net Income / Total Assets & ROA \\
\hline Growth (Sales' Growth) & [Sales Sales $_{\mathrm{t}-1}$ ] / Sales $\mathrm{s}_{\mathrm{t}-1}$ & GROWTH \\
\hline Size (Natural Logarithm of Total Assets) & In(Total Assets) & InSIZE \\
\hline
\end{tabular}

The regression equations in order test possible relationships between profitability and growth, and between profitability and size are as given as given below: 


$$
\begin{aligned}
& R O A_{t}=\beta_{0}+\beta_{1} \text { GROWTH }_{t}+\varepsilon_{t} \\
& R O A_{t}=\beta_{0}+\beta_{1} \operatorname{lnSIZE}_{t}+\varepsilon_{t}
\end{aligned}
$$

In the model, profitability, growth and size variables are denoted by ROA, GROWTH and InSIZE, respectively.

\section{METHODOLOGY and EMPIRICAL FINDINGS}

This study tries to find out the inter-relationship between profitability, growth and size via various empirical analyses including (1) multiple structural breaks unit root test of Carrioni-i-Silvestre et. al. (2009), (2) multiple structural breaks co-integration test of Maki (2012), (3) dynamic ordinary least squares (DOLS) method developed by Stock and Watson (1993) and (4) bootstrap causality test developed by Hacker and Hatemi-J (2012), respectively.

\subsection{Multiple Structural Breaks Unit Root Test of Carrion-i-Silvestre et. al. (2009)}

The results derived from traditional unit root tests may sometimes be misleading when major events like economic crises, wars, catastrophes, etc. have influence on the data analyzed, as these events have tendency to create structural breaks in the series. In these cases, unit root tests allowing for the presence of multiple structural breaks should be referred. The multiple structural breaks unit root test developed by Carrioni-i-Silvestre et. al. (2009: 1786) is one of them allowing for the presence of multiple breaks affecting the individual effects and time trend under the endogenous structural break assumptions; and also offers improvements over commonly methods in even small samples (as the one in this study). In this study, this unit root test is employed because of its superiority to other similar tests, especially about the total number of presence of multiple breaks (maximum up to five).

Carrioni-i-Silvestre et. al. (2009: 1786) see their study as an extension of Kim and Perron (2009)'s work by (1) allowing for an arbitrary number of changes in both the level and slope of the trend function; (2) adopting the so-called quasi-generalized least squares (quasi-GLS) detrending method advocated by Elliot et. al. (1996); and (3) considering the class of $M$-tests introduced in Stock (1999) and analyzed in Ng and Perron (2001).

In their model, $y_{t}$ is the stochastic process generated according to:

$y_{t}=d_{t}+u_{t}$

$u_{t}=\alpha u_{t-1}+v_{t}, \quad t=0, \ldots, T$

where $\left\{\mathrm{u}_{\mathrm{t}}\right\}$ is an unobserved mean-zero process. It is assumed that $u_{0}=0$. The disturbance term $v_{t}$ is defined by $v_{t}=\sum_{i=0}^{\infty} \gamma_{i} \eta_{t-i}$ with $\sum_{i=0}^{\infty} i\left|\gamma_{i}\right|<\infty$ and $\left\{\eta_{t}\right\}$ a martingale difference sequence adopted to the filtration $F_{t}=\sigma-$ field $\left\{\eta_{t-1} ; i \geq 0\right\}$. The short-run and long-run variance are defined as $\sigma^{2}=\sigma_{\eta}^{2} \gamma(1)^{2}$ and $\sigma_{\eta}^{2}=\lim _{T \rightarrow \infty} T^{-1} \sum_{t}^{T} E\left(\eta_{t}^{2}\right)$, respectively. 
Carrioni-i-Silvestre et. al. (2009) have developed five test statistics. The first one is based on the analyses of Elliot et. al. (1996) and Perron and Rodriguez (2003). Here the feasible point optimal statistic is given by:

$P_{T}^{G L S}\left(\lambda^{0}\right)=\left\{S\left(\bar{\alpha}, \lambda^{0}\right)-\bar{\alpha} S\left(1, \lambda^{0}\right)\right\} / s^{2}\left(\lambda^{0}\right)$

where $s^{2}\left(\lambda^{2}\right)$ is an estimate of the spectral density at frequency zero of $v_{t}$. Following Perron and Ng (1998) and Ng and Perron (2001), Carrioni-i-Silvestre et. al. (2009) use an autoregressive estimate defined by:

$s\left(\lambda^{0}\right)^{2}=s_{e k}^{2} /\left(1-\sum_{j=1}^{k} \hat{b}_{j}\right)^{2}$

where $s_{e k}^{2}=(T-k)^{-1} \sum_{t=k+1}^{T} \hat{e}_{t, k}^{2}$ and $\left\{\hat{b}_{j}, \hat{e}_{t, k}\right\}$ obtained from the ordinary least squares (OLS) regression:

$\Delta \tilde{y}_{t}=b_{0} \tilde{y}_{t-1}+\sum_{j=1}^{k} b_{j} \Delta \tilde{y}_{t-j}+e_{t, k}$

with $\tilde{y}_{t}=y_{t}-\widehat{\Psi}^{\prime} z_{t}\left(\lambda^{0}\right)$ where $\widehat{\Psi}$ minimizes the objective function ${ }^{1}$.

The order of autoregression $k$ is selected using the modified information criteria suggested by $\mathrm{Ng}$ and Perron (2001) and with the modification proposed by Perron and Qu (2007).

The three $M$-class of tests allowing for multiple structural breaks used by Carrioni-iSilvestre et. al. (2009) are defined by Equations 6-8 as given below. These tests have been analyzed previously in $\mathrm{Ng}$ and Perron (2001).

$\operatorname{MZ}_{\alpha}^{G L S}\left(\lambda^{0}\right)=\left(T^{-1}-s\left(\lambda^{0}\right)^{2}\right)\left(2 T^{-2} \sum_{t=1}^{T} \tilde{y}_{t-1}^{2}\right)^{-1}$
$\operatorname{MSB}^{G L S}\left(\lambda^{0}\right)=\left(s\left(\lambda^{0}\right)^{-2} T^{-2} \sum_{t=1}^{T} \tilde{y}_{t-1}^{2}\right)^{\frac{1}{2}}$
$\operatorname{MZ}_{t}^{G L S}\left(\lambda^{0}\right)=\left(T^{-1} \tilde{y}_{T}^{2}-s\left(\lambda^{0}\right)^{2}\right)\left(4 s\left(\lambda^{0}\right)^{2} T^{-2} \sum_{t=1}^{T} \tilde{y}_{t-1}^{2}\right)^{-\frac{1}{2}}$

with $\tilde{y}_{t}=y_{t}-\widehat{\Psi}^{\prime} z_{t}\left(\lambda^{0}\right)$, where $\widehat{\Psi}$ minimizes the objective function given in the footnote 1 and $s\left(\lambda^{0}\right)^{2}$ is defined in Equation (4).

Following Ng and Perron (2001), the fifth statistic in Carrioni-i-Silvestre et. al. (2009) is a modified feasible point optimal test defined by:

\footnotetext{
${ }^{1}$ The so-called GLS detrended unit root test statistics are based on the use of the quasi-differenced variables $y_{t}^{\bar{\alpha}}$ and $z_{t}^{\bar{\alpha}}\left(\lambda^{0}\right)$ defined by $y_{1}^{\bar{\alpha}}=y_{1}, \quad z_{1}^{\bar{\alpha}}\left(\lambda^{0}\right)=z_{1}\left(\lambda^{0}\right)$, and $y_{t}^{\bar{\alpha}}=(1-\bar{\alpha} L) y_{t}, \quad z_{t}^{\bar{\alpha}}\left(\lambda^{0}\right)=(1-\bar{\alpha} L) z_{t}\left(\lambda^{0}\right)$ for $t=2, \ldots, T$ with $\bar{\alpha}=1+\bar{c} / T$ where $\bar{c}$ is a noncentrality parameter. Once the data have been transformed, the parameters $\Psi$, associated with the deterministic components, can be estimated by minimizing the following objective function: $S^{*}\left(\Psi, \bar{\alpha}, \lambda^{0}\right)=\sum_{t=1}^{T}\left(y_{t}^{\bar{\alpha}}-\Psi_{t}^{\bar{\alpha}}\left(\lambda^{0}\right)\right)^{2}$. The minimum of this function is denoted by $S\left(\bar{\alpha}, \lambda^{0}\right)$ (Carrioni-i-Silvestre et. al., 2009: 1758-1759).
} 
$M P_{T}^{G L S}\left(\lambda^{0}\right)=\frac{\left[c^{-2} T^{-2} \sum_{t=1}^{T} \tilde{y}_{t-1}^{2}+(1-\bar{c}) T^{-1} \tilde{y}_{T}^{2}\right]}{s\left(\lambda^{0}\right)^{2}}$

In Carrioni-i-Silvestre et. al. (2009), asymptotic critical values are obtained by using the bootstrap. The null hypothesis of a unit root is rejected in case of calculated test statistics being smaller than critical values. In this situation, it can be said that series is stationary under the presence of structural break. Results of unit root test of Carrioni-i-Silvestre et. al. (2009) are given in Table 2.

Table 2.: Results of Unit Root Test of Carrion-i-Silvestre et. al. (2009)

\begin{tabular}{|c|c|c|c|c|c|c|}
\hline \multirow{2}{*}{ Variable } & \multicolumn{5}{|c|}{ Critical Values } & \multirow{2}{*}{ Break Dates } \\
\hline & $P_{T}^{G L S}$ & $M Z_{\alpha}^{G L S}$ & $M S B^{G L S}$ & $M Z_{t}^{G L S}$ & $M P_{T}^{G L S}$ & \\
\hline$R O A$ & $\begin{array}{l}13.236 \\
(8.869) \\
\end{array}$ & $\begin{array}{l}-33.102 \\
(-46.219) \\
\end{array}$ & $\begin{array}{c}0.122 \\
(0.103) \\
\end{array}$ & $\begin{array}{c}-4.066 \\
(-4.786) \\
\end{array}$ & $\begin{array}{l}12.534 \\
(8.869) \\
\end{array}$ & $\begin{array}{c}\text { 1993.Q4; 1996.Q2; 1999.Q2; } \\
\text { 2001.Q4; 2008.Q2 }\end{array}$ \\
\hline InSIZE & $\begin{array}{l}24.236 \\
(9.250)\end{array}$ & $\begin{array}{l}-21.739 \\
(-47.749)\end{array}$ & $\begin{array}{c}0.151 \\
(0.101)\end{array}$ & $\begin{array}{l}-3.285 \\
(-4.877)\end{array}$ & $\begin{array}{l}20.792 \\
(9.250)\end{array}$ & $\begin{array}{c}\text { 1993.Q3; 1998.Q1; 2003.Q3; } \\
\text { 2006.Q1; 2010.Q4 }\end{array}$ \\
\hline GROWTH & $\begin{array}{l}13.039 \\
(9.169) \\
\end{array}$ & $\begin{array}{l}-36.538 \\
(-46.490) \\
\end{array}$ & $\begin{array}{c}0.116 \\
(0.103) \\
\end{array}$ & $\begin{array}{c}-4.274 \\
(-4.806) \\
\end{array}$ & $\begin{array}{l}11.817 \\
(9.169) \\
\end{array}$ & $\begin{array}{c}\text { 1993.Q2; 1999.Q1; 2001.Q4; } \\
\text { 2009.Q1; 2011.Q4 }\end{array}$ \\
\hline$\triangle R O A$ & $\begin{array}{l}2.358 * * \\
(5.543)\end{array}$ & $\begin{array}{l}-38.138^{* *} \\
(-17.325) \\
\end{array}$ & $\begin{array}{l}0.114^{* *} \\
(0.168)\end{array}$ & $\begin{array}{c}-4.363^{* *} \\
(-2.896) \\
\end{array}$ & $\begin{array}{l}2.409 * * \\
(5.543)\end{array}$ & \\
\hline$\triangle / n S I Z E$ & $\begin{array}{l}2.141 * * \\
(5.543)\end{array}$ & $\begin{array}{c}-44.517^{* *} \\
(-17.325) \\
\end{array}$ & $\begin{array}{c}0.105^{* *} \\
(0.168)\end{array}$ & $\begin{array}{l}-4.710^{* *} \\
(-2.896)\end{array}$ & $\begin{array}{l}2.087^{* *} \\
(5.543)\end{array}$ & \\
\hline$\triangle G R O W T H$ & $\begin{array}{c}2.804^{* *} \\
(5.543)\end{array}$ & $\begin{array}{c}-40.055^{* *} \\
(-17.325)\end{array}$ & $\begin{array}{c}0.111^{* *} \\
(0.168)\end{array}$ & $\begin{array}{c}-4.468^{* *} \\
(-2.896)\end{array}$ & $\begin{array}{c}2.311^{* *} \\
(5.543)\end{array}$ & \\
\hline
\end{tabular}

$\Delta$ denote stationarity at significance level of $5 \%$; and the first difference, respectively.

According to the empirical results, the null hypotheses of a unit root test is accepted as calculated test statistics at level are bigger than critical values. Test results also indicate that series are stationary at their first differences and integrated of order one, I(1).

As seen in Table 2, structural break dates estimated by the unit root test of Carrion-iSilvestre et. al. (2009) point out dramatic turning points in Turkish economy. These break dates are to be discussed in the Conclusion part of the study.

\subsection{Multiple Structural Breaks Co-integration Test of Maki (2012)}

Among co-integration tests considering structural breaks, tests suggested by Zivot and Andrews (1992); Gregory and Hansen (1996), and Westerlund and Edgerton (2007) allow only one structural break. However, Gregory and Hansen (1996) criticizes that in case of referring such tests, breaks may cause spurious unit root behavior in the co-integrating relationship. So, multiple (at least more than one) structural breaks should be processed in co-integration tests. In this context, tests developed by Carrion-i-Silvestre and Sanso (2006) and Hatemi-J (2008) allow two structural breaks. Additionally, Maki (2012) proposes a test performing better than its ancestors when the co-integration relationship has more than three (maximum up to five) breaks or persistent Markov switching shifts. Therefore in this study, Maki (2012) co-integration test is used. Maki (2012) tries to identify the long-run relationships between series with four different regression models in as given below: 
$y_{t}=\mu+\sum_{i=1}^{k} \mu_{i} D_{i, t}+\beta^{\prime} x_{t}+\mu_{t}$

$y_{t}=\mu+\sum_{i=1}^{k} \mu_{i} D_{i, t}+\beta^{\prime} x_{t}+\sum_{i=1}^{k} \beta_{i}^{\prime} x_{t} D_{i, t}+\mu_{t}$

$y_{t}=\mu+\sum_{i=1}^{k} \mu_{i} D_{i, t}+\gamma t+\beta^{\prime} x_{t}+\sum_{i=1}^{k} \beta_{i}^{\prime} x_{t} D_{i, t}+\mu_{t}$

$y_{t}=\mu+\sum_{i=1}^{k} \mu_{i} D_{i, t}+\gamma t+\sum_{i=1}^{k} \gamma_{i} t D_{i, t}+\beta_{i} x_{t}+\sum_{i=1}^{k} \beta_{i}^{\prime} x_{t} D_{i, t}+u_{t}$

where $t=1,2, \ldots, T . y_{t}$ and $x_{t}=\left(x_{t} \ldots x_{m t}\right)^{\prime}$ denote observable $1(1)$ variables, and $u_{t}$ is the equilibrium error. $y_{t}$ is a scalar and $x_{t}=\left(x_{1 t}, \ldots, x_{m t}\right)^{\prime}$ is an $(m \times 1)$ vector. It is assumed that an $(n \times 1)$ vector $z_{t}$ is generated byz $z_{t}=\left(y_{t}, x_{t}^{\prime}\right)^{\prime}=z_{t-1}+\varepsilon_{t}$, where $\varepsilon_{t}$ are independent identically distributed with mean zero, definite variance-covariance matrix $\Sigma$, and $E\left|\varepsilon_{t}\right|^{s}<\infty$ for some $s>4 . \mu, \mu_{i}, \gamma, \gamma_{i}, \beta=\left(\beta_{i 1}, \ldots, \beta_{i m}\right)$ are true parameters. $D_{i, t}$ takes as value of 1 if $t>T_{B i}(i=1, \ldots, k)$ and of 0 otherwise, where $k$ is the maximum number of breaks and $T_{B i}$ denotes the time period of the break.

The first model with level shifts and without trend in which there is a break in the constant term, and the second model (also called as the regime-shifts model) without trend in which there are breaks in both constant term and slope are given in Equations (10) and (11), respectively. The third model given in Equation (12) is the second model with a trend. The fourth and the last model is the comprehensive one with breaks in constant term, slope and trend (Equation 13).

The asymptotic critical values of the tests for the maximum number of breaks (from 1 to 5 ) approximated by Monte Carlo simulations coded by GAUSS are given in Maki (2012). The null hypothesis of non-existence of co-integration between series is rejected in case of calculated test statistics being smaller than these critical values. In the study, null hypothesis is accepted for the $1^{\text {st }}$ model, while it is rejected for the $2^{\text {nd }}$ one. Therefore, there exists a co-integration relationship between firm profitability and size. The results of multiple structural breaks co-integration test of Maki (2012) are given in Table 3.

As seen in Table 3, calculated test statistics being smaller than critical values point out that alternative hypothesis of existence of co-integration between the series under multiple structural breaks is accepted. Maki (2012) test results show that the series are cointegrated in the long-run. In the next step of the analysis, estimation of long-run parameters are made by using the dynamic ordinary least squares (DOLS) method developed by Stock and Watson (1993). Break dates obtained from co-integration test are also included in the model developed for parameter estimation. 
Table 3.: Results of Maki (2012) Co-integration Tests

\begin{tabular}{|c|c|c|c|c|c|c|c|c|}
\hline & & \multirow{2}{*}{ Models } & \multirow{2}{*}{$\begin{array}{c}\text { Test } \\
\text { Statistics }\end{array}$} & \multicolumn{3}{|c|}{ Critical Values } & \multirow{2}{*}{ Break Dates } & \multirow{2}{*}{$\begin{array}{c}\text { Existence } \\
\text { of Co- } \\
\text { integration }\end{array}$} \\
\hline & & & & $1 \%$ & $5 \%$ & $10 \%$ & & \\
\hline \multirow{4}{*}{$\begin{array}{l}\pi \\
5 \\
3 \\
0 \\
0 \\
0 \\
1 \\
\pi \\
0 \\
0\end{array}$} & \multirow{4}{*}{ 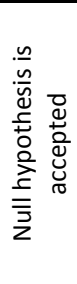 } & Model 0 & -3.934 & -5.959 & -5.426 & -5.131 & $\begin{array}{c}\text { 1992.Q4; 1998.Q4; 2001.Q1; } \\
\text { 2001.Q4; 2008.Q4 }\end{array}$ & - \\
\hline & & Model 1 & -4.561 & -6.193 & -5.699 & -5.449 & $\begin{array}{c}\text { 1992.Q3; 1998.Q4; 2000.Q3; } \\
\text { 2001.Q4; 2005.Q3 }\end{array}$ & - \\
\hline & & Model 2 & -5.222 & -6.915 & -6.357 & -6.057 & $\begin{array}{c}\text { 1993.Q4; 1999.Q4; 2000.Q3; } \\
\text { 2000.Q4; 2011.Q1 }\end{array}$ & - \\
\hline & & Model 3 & -5.777 & -8.004 & -7.414 & -7.110 & $\begin{array}{c}\text { 1992.Q3; 1994.Q2; 1995.Q4; } \\
\text { 1998.Q4; 2001.Q4 }\end{array}$ & - \\
\hline \multirow{4}{*}{ 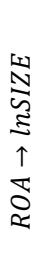 } & \multirow{4}{*}{ 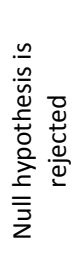 } & Model 0 & -4.628 & -5.959 & -5.426 & -5.131 & $\begin{array}{c}\text { 1992.Q4; 1995.Q1; 1998.Q4; } \\
\text { 2001.Q4; 2011.Q2 }\end{array}$ & - \\
\hline & & Model 1 & $-5.788 * *$ & -6.195 & -5.699 & -5.449 & $\begin{array}{c}\text { 1992.Q4; 1995.Q1; 1998.Q4; } \\
\text { 2001.Q4; 2011.Q2 }\end{array}$ & + \\
\hline & & Model 2 & -5.752 & -6.915 & -6.357 & -6.057 & $\begin{array}{c}\text { 1993.Q4; 1996.Q4; 1998.Q4; } \\
\text { 2001.Q4; 2005.Q1 }\end{array}$ & - \\
\hline & & Model 3 & -6.984 & -8.004 & -7.414 & -7.110 & $\begin{array}{c}\text { 1995.Q4; 1999.Q4; 2001.Q4; } \\
\text { 2008.Q3; 2012.Q2 }\end{array}$ & - \\
\hline
\end{tabular}

Note: Critical values are obtained from the Table 1 in Maki (2012)'s study. **, denotes significance level of $5 \%$.

\subsection{Estimation of Long-run Parameters}

DOLS method of Stock and Watson (1993) is improved on ordinary least squares (OLS) having certain advantages over both it and the maximum likelihood procedures such as coping with small sample and dynamic sources of bias. As a robust single equation approach, DOLS corrects for regressor endogeneity by the inclusion of leads and lags of the first differences of the regressors, and for serially correlated errors by a generalized least squares (GLS) procedure (Esteve and Requena, 2006: 118). Moreover, it has the same asymptotic optimality properties as the Johansen (1991) distribution (Al-Azzam and Hawdon, 1999). Using DOLS estimators requires existence of co-integration between dependent and explanatory series.

The DOLS estimator is obtained from the Equation (14):

$y_{t}=\alpha_{0}+\alpha_{1} t+\alpha_{2} x_{t}+\sum_{i=-q}^{q} \delta_{i} \Delta x_{t-i}+\varepsilon_{t}$

where $q$ represent optimum leads and lags, and $\varepsilon_{\mathrm{t}}$ error term, respectively.

The long-run parameters estimated by DOLS method given in Table 4 indicate that the only statistically significant relationship is between profitability and size. Accordingly, size has statistically negative effect on profitability. This empirical result may be discussed in terms of diseconomies of scale.

\subsection{Bootstrap Causality Test of Hacker and Hatemi-J (2012)}

As co-integration analyses do not provide information on the direction of causality, causality analysis should be undertaken in determining causal relationships between the series. For this purpose, the bootstrap causality test of Hacker and Hatemi-J (2012) is used in this study. In their previous study, Hacker and Hatemi-J (2006) have used the Granger 
causality Wald test with a modification for integrated variables suggested in Toda and Yamamoto (1995), concluding that such test is not appropriate to be used with relatively small sample sizes. Therefore, in 2012, they have improved their test by assuming the lag length to be unknown and the one chosen is data-driven; presenting the power and simulation results; and focusing on smaller sample sizes (20-40 observations).

Table 4.: DOLS Estimation Results (Model 2)

\begin{tabular}{|c|c|c|c|}
\hline Variables & Coefficients & $t$-statistics & Prob. \\
\hline Ln SIZE & $-0.004 * * *$ & -1.785 & 0.078 \\
\hline$D 1$ & -0.047 & -0.696 & 0.488 \\
\hline$D 2$ & 0.147 & 2.397 & 0.019 \\
\hline$D 3$ & 0.015 & 0.263 & 0.793 \\
\hline$D 4$ & -0.166 & -2.846 & 0.005 \\
\hline$D 5$ & 0.071 & 0.058 & 0.226 \\
\hline$C$ & 0.139 & 2.629 & 0.010 \\
\hline$R^{2}: 0.58$ & \multicolumn{3}{|c}{ D-W test statistics: 1.013} \\
\hline
\end{tabular}

Note: ${ }^{* * *}$, denotes significance level of $10 \%$.

In the context of Granger causality, Hacker and Hatemi-J (2012) consider the vector autoregressive model of order $k, \operatorname{VAR}(k)$;

$\gamma_{t}=\beta_{0}+\beta_{1} \gamma_{t-1}+\cdots+\beta_{k} \gamma_{t-k}+\mu_{t}$

where $\gamma_{t}, \beta_{0}$ and $\mu_{t}$ are vectors with dimensions $n \times 1$ and $\beta_{i}, i \geq 1$ is a parameter matrix with $n \times n$ dimensions. The error vector, $\mu_{t}$, has a zero-expected value, assumed to be independent and identically distributed with a non-singular covariance matrix $\Omega$. The lag length, $k$, is determined by estimating the $\operatorname{VAR}(k)$ model in Equation (15) for $k=0, \ldots, K$, where $K$ is the maximum lag length considered, and finding that $k$ which minimizes the information criterion suggested by Hatemi-J $(2003 ; 2008)$ as an alternative to Schwarz Bayesian Information Criterion $(S B C)$ and Akaike Information Criterion $(A / C)$. Hatemi-J Information Criterion $(H J C)$ is as below:

$H J C=\ln \left(\operatorname{det} \widehat{\Omega}_{k}\right)+k\left(\frac{n^{2} \ln T+2 n^{2} \ln (\ln T)}{2 T}\right) \quad k=0, \ldots, K$

where $\ln$ is the natural logarithm; $\operatorname{det} \widehat{\Omega}_{k}$ is the determinant of the estimated variancecovariance matrix of the residuals in the $\operatorname{VAR}(k)$ model for lag order $k ; n$ and $T$ are the number of variables and the sample size (number of observations), respectively.

In case of variables being integrated, standard asymptotical distributions cannot be used to test for restrictions in the $V A R$ model. To overcome this problem, Toda and Yamamoto (1995) uses an augmented $\operatorname{VAR}(k+d)$ model, where $d$ denotes integration order of variables. This model can be written compactly as below (Hatemi-J et. al., 2006: 69): 
$Y=D Z+\delta$

To test the null hypothesis of non-Granger causality, the modified Wald (MWALD) test statistic is used. This test is as:

$M W A L D=(Q \hat{\beta})^{\prime}\left[Q\left(\left(\mathrm{Z}^{\prime} \mathrm{Z}\right)^{-1} \Theta \Omega_{U}\right) Q^{\prime}\right]^{-1}(Q \hat{\beta}) \sim \chi_{k}^{2}$

where $Q$ is an $k \times n(1+n(k+d))$ indicator matrix used to identify restrictions implied by the null hypothesis; and $\Theta$ is the element by all element matrix multiplication operator (the Kronecker product. $\Omega_{U}$ is the estimated variance-covariance matrix of residuals in Equation (17) when the restrictions implied by the null hypothesis of non-Granger causality is not imposed and is determined by the formula $\Omega_{U}=\left(\delta_{U} \delta \delta_{U}\right) \div(T-$ $(1+n k))$, where $(1+n k)$ is the number of parameters.

Under the normal distribution assumption, the Wald test statistics follows a $\chi^{2}$ distribution with $k$ degrees of freedom asymptotically. However, in cases where sample size is relatively small; the error terms are not normally distributed; and autoregressive conditional heteroscedasticity effects exist, asymptotic critical values of the Wald test are not precise. For the solution of this problem, Hacker and Hatemi-J (2012) suggest a test based on leveraged bootstrap simulations emphasizing that when the lag length choice is endogenized, the suggested test will perform better with more precise results. The null hypothesis non-Granger causality is rejected in case of calculated Wald statistic being higher than the bootstrap critical value. The causality relationships among variables are given in Table 5.

Table 5.: Bootstrap Causality Test of Hacker and Hatemi-J (2012)

\begin{tabular}{|c|c|c|c|c|}
\hline The Null Hypothesis & $\begin{array}{c}\text { MWALD } \\
\text { Statistics }\end{array}$ & $\begin{array}{c}1 \% \\
\text { Critical Value }\end{array}$ & $\begin{array}{c}5 \% \\
\text { Critical Value }\end{array}$ & $\begin{array}{c}10 \% \\
\text { Critical Value }\end{array}$ \\
\hline No Causality from ROA to GROWTH & 1.544 & 6.939 & 3.768 & 2.716 \\
\hline No Causality from GROWTH to ROA & 0.211 & 6.737 & 3.947 & 2.748 \\
\hline No Causality from ROA to InSIZE & $4.982^{* * *}$ & 11.164 & 6.102 & 4.676 \\
\hline No Causality from InSIZE to ROA & 0.364 & 10.431 & 6.346 & 4.923 \\
\hline
\end{tabular}

Note: $* * *$, denotes significance level of $10 \%$. The bootstrapping is repeated 10,000 times.

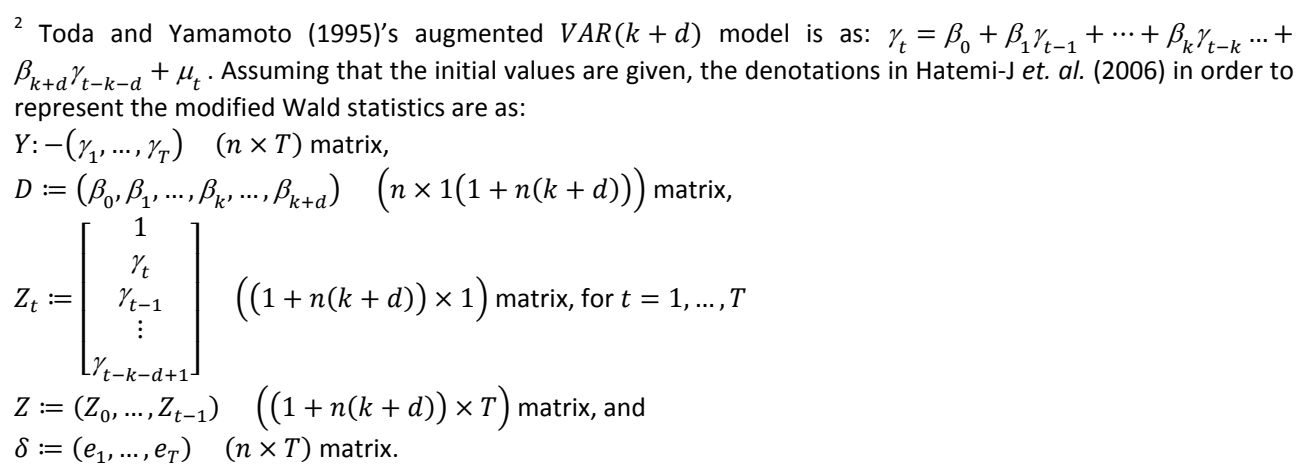


Bootstrap causality test results indicate the existence of one-way causality from size to profitability variable at significance level of $10 \%$ for the manufacturing industry (firms) in Turkey. The result imply that (firm) size statistically affects (firm) growth.

\section{CONCLUSION}

This study investigates the inter-relationship between firm profitability, growth and size in Turkish manufacturing industry consisting of Borsa Istanbul listed manufacturing firms covering 1991.Q2-2014.Q4. In the study, the stationarity of series are tested by unit root test of Carrioni-i-Silvestre et. al. (2009. The structural break dates estimated by this test point out dramatic turning points in Turkish economy. Last quarter of the year 1993 is seen as the beginning period of Turkey's currency crisis in 1994. As known, huge public sector borrowing requirements and major policy fallacies in financing the deficit have led to a currency crash in Turkey in 1994. After five years, on August $17^{\text {th }}$ and November 12th, 1999, earthquakes struck the Marmara and Bolu areas of Turkey causing high casualties and significant material damage on property, with severe effects on economy. Following, a new crisis occurred on February $19^{\text {th }}, 2001$ in the form of a virtual raid on foreign currencies. Finally, along with the world economy, Turkish economy faced with the financial crisis of 2007-08 (also known as Global Credit Crunch or 2008 Financial Crisis) considered by many economists to have been the worst financial crisis since the Great Depression.

Besides, co-integration relationship and co-integration coefficients between profitability, growth and size are tested by means of co-integration test of Maki (2012) and Stock and Watson (1993)'s dynamic ordinary least squares (DOLS) method, respectively. The results of Maki (2012) test indicate a co-integration relationship between firm profitability and size. The long parameters estimated by DOLS method show that the only statistically significant relationship is between firm profitability and size. Accordingly, size has statistically negative effect on profitability indicating that firm profitability decreases due to increase in size. This finding supports to the theory of diseconomies of scale. In diseconomies of scale, long-term average cost of production increases due to increase in the scale of operations beyond a certain level.

Finally, causal relationships between the variables are also tested by Hacker and Hatemi-J (2012) bootstrap causality test. Results of this test indicate only the existence of one-way causality from size to profitability.

This study is subject to some limitations. The findings of the study cannot be generalized to other industries, as the sample consists of only the manufacturing industry. Besides, the profitability, growth and size variables used in the study may be changed with the ones discussed in the $3^{\text {rd }}$ part of the study. So, further studies may investigate the mentioned inter-relationships using other various variables with more enlarged samples consisting of different industries. 


\section{REFERENCES}

Akbaş, H.E. and H.A. Karaduman, 2012, "The Effect of Firm Size on Profitability: An Empirical Investigation on Turkish Manufacturing Companies", European Journal of Economics, Finance and Administrative Sciences, 55, 21-27.

Al-Azzam, A. and D. Hawdon, 1999, "Estimating the Demand for Energy in Jordan: A StockWatson Dynamic OLS (DOLS) Approach", Surrey Energy Economics Discussion Papers, University of Surrey.

Alchian, A., 1950, "Uncertainty, Evolution, and Economic Theory", The Journal of Political Economy, 58, 211-221.

Alexander, S.S., 1949, "The Effect of Size of Manufacturing Corporation on the Distribution of the Rate of Return", Review of Economics and Statistics, 31, 229-235.

Amato, L.H. and R.P. Wilder, 1985, "The Effects of Firm Size on Profit Rate in U.S. Manufacturing", Southern Economics Journal, 52, 181-190.

Amato, L.H. and T.E. Burson, 2007, "The Effects of Firm Size on Profit Rates in the Financial Services", Journal of Economics and Economic Education Research, 8, 67-81.

Anderson, C.W. and A.K. Makhija, 1999, "Deregulation, Disintermediation, and Agency Costs of Debt: Evidence from Japan", Journal of Financial Economics, 51, 309-339.

Archarungroj, P. and Y. Hoshino, 1998, "The Impact of Firm Size on Export Performance and Attitudes: An Empirical Study on Thailand Exporters", Japanese Journal of Administrative Science, 12, 79-88.

Asimakopoulous, I., A. Samitas and T. Papadogonas, 2009, "Firm-specific and Economy Wide Determinants of Firm Profitability: Greek Evidence Using Panel Data", Managerial Finance, 35, 930-939.

Barkham, R., G. Gudgin, M. Hart and E. Hanvey, 1996, "The Determinants of Small Firm Growth: An Interregional Study in the UK, 1986-90", Jessica Kingsley, London.

Becker-Blease, J.R., F.R. Kaen, A. Etebari and H. Baumann, 2010, “Employees, Firm Size and Profitability in U. S. Manufacturing Industries", Investment Management and Financial Innovations, 7, 7-23.

Bokhari, H.W. and M.A. Khan, 2013, "The Impact of Capital Structure on Firm's Performance: A Case of Non-Financial Sector of Pakistan", European Journal of Business and Management, 5, 111-137.

Bonaccorsi, A. 1992, "On the Relationship between Firm Size and Export Intensity", Journal of International Business Studies, 23, 605-636.

Booth, L., V. Aivazian, A. Demirguc-Kunt and V. Maksimovic, 2001, "Capital Structure in Developing Countries", The Journal of Finance, 56, 87-130. 
Bottazzi, G., G. Dosi, N. Jacoby, A. Secchi and F. Tamagni, 2010, "Corporate Performances and Market Selection: Some Comparative Evidence", Industrial and Corporate Change, 19, 1953-1996.

Bottazzi, L., M. Da Rin and T. Hellmann, 2008, "Who are the Active Investors? Evidence from Venture Capital", Journal of Financial Economics, 89, 488-512.

Brännback, M., A. Carsrud, M. Renko, R. Östermark, J. Aaltonen and N. Kiviluoto, 2009, "Growth and Profitability in Small Privately Held Biotech Firms: Preliminary Findings", New Biotechnology, 25, 369-376.

Capon, N., J.U. Farley and S. Hoenig, 1990, “Determinants of Financial Performance: A Meta-analysis", Management Science, 36, 1143-1159.

Carrioni-i-Silvestre, J.L. and A. Sanso, 2006, "Testing the Null of Co-integration with Structural Breaks", Oxford Bulletin of Economics and Statistics, 68, 623-646.

Carrioni-i-Silvestre, J.L., D. Kim and P. Perron, 2009, "GLS-Based Unit Root Tests with Multiple Structural Breaks under Both the Null and the Alternative Hypothesis", Econometric Theory, 25, 1754-1792.

Chandler, G.N. and E. Jansen, 1992, "The Founder's Self-assessed Competence and Venture Performance", Journal of Business Venturing, 7, 223-236.

Claver, E., J. Molina and J. Tari, 2002, "Firm and Industry Effects on Firm Profitability: A Spanish Empirical Analysis", European Management Journal, 20, 321-328.

Coad, A., 2007, "Testing the Principle of "Growth of the Fitter": The Relationship between Profits and Firm Growth", Structural Change and Economic Dynamics, 18, 370-386.

Coad, A., 2009, The Growth of Firms: A Survey of Theories and Empirical Evidence, Edward Elgar Publishing.

Coad, A., 2010, "Exploring the Processes of Firm Growth: Evidence from a Vector Autoregression", Industrial and Corporate Change, 19, 1677-703.

Cowling, M., 2004, "The Growth-Profit Nexus", Small Business Economics, 22, 1-9.

Cox, H., S. Mowatt and M. Prevezer, 2002, "The Firm in the Information Age: Organizational Responses to Technological Change in the Processed Food Sector", Industrial and Corporate Change, 11, 135-158.

Dalbor, M.C., A. Kim and A. Upneja, 2004, "An Initial Investigation of Firm Size and Debt Use by Small Restaurant Firms", Journal of Hospitality Financial Management, 12, 41-48.

Davidsson, P., P. Steffens and J. Fitzsimmons, 2009, "Growing Profitable or Growing from Profits: Putting the Horse in front of the Cart?", Journal of Business Venturing, 24, 388406.

Deesomsak, R., K. Paudyal and G. Pescetto, 2004, "The Determinants of Capital Structure: Evidence from the Asia Pacific Region", Journal of Multinational Financial Management, 14, 387-405. 
Delmar, F., 1997, "Measuring Growth: Methodological Considerations and Empirical Results", in Donckels, R., A. Miettinen (Eds.), Entrepreneurship and SME Research: On Its Way to the Next Millennium, Ashgate Publishing Ltd., Hants, England, 199-215.

Delmar, F., A. McKelvie and K. Wennberg, 2013, "Untangling the Relationships among Growth, Profitability and Survival in New Firms", Technovation, 33, 276-291.

Doğan, M., 2013, "Does Firm Size Affect the Firm Profitability? Evidence from Turkey", Research Journal of Finance and Accounting, 4, 53-59.

Donaldson, G., 1961, Corporate Debt Capacity: A Study of Corporate Debt Policy and the Determination of Corporate Debt Capacity, Boston: Division of Research, Harvard School of Business Administration.

Ebaid, I.E., 2009, "The Impact of Capital Structure Choice on Firm Performance: Empirical Evidence from Egypt", Journal of Risk Finance, 10, 477-487.

Elliot, G., T.J. Rothenberg and J.H. Stock, 1996, "Efficient Tests for an Autoregressive Time Series with a Unit Root", Econometrica, 64, 813-836.

Esteve, V. and F. Requena, 2006, "A Co-integration Analysis of Car Advertising and Sales Data in the Presence of Structural Change", International Journal of the Economics of Business, 13, 111-128.

Fareed, Z., S. Aziz, S. Naz, F. Shahzad, M. Arshad and Umm-e-Amen (2014), "Testing the Relationship between Profitability and Capital Structure of Textile Industry of Pakistan", World Applied Sciences Journal, 29, 605-609.

Ferati, R. and E. Ejupi, 2012, "Capital Structure and Profitability: The Macedonian Case", European Scientific Journal, 8, 51-58.

Fiegenbaum, A. and A. Karnani, 1991, “Output Flexibility - A Competitive Advantage for Small Firms", Strategic Management Journal, 12, 101-114.

Fitzsimmons, J.R., P.R. Steffens and E.J. Douglas, 2005, Growth and Profitability in Small and Medium Sized Australian Firms, AGSE Entrepreneurship Exchange, Melbourne, February.

Frank, M.Z. and V.K. Goyal, 2003, "Testing the Pecking Order Theory of Capital Structure", Journal of Financial Economics, 67, 217-248.

Friend, I. and L.H.P. Lang, 1988, "An Empirical Test of the Impact of Managerial SelfInterest on Corporate Capital Structure", The Journal of Finance, 43, 271-281.

Gale, B.T., 1972, "Market Share and Rate of Return", Review of Economics and Statistics, $54,412-423$.

Glancey, K., 1998, "Determinants of Profitability in Small Entrepreneurial Firms", International Journal of Entrepreneurial Behavior and Research, 4, 14-15. 
Goddard, J., P. Molyneux and J. Wilson, 2006, "Do Firm Sizes and Profit Rates Converge? Evidence on Gibrat's Law and the Persistence of Profits in the Long Run", Applied Economics, 38, 267-278.

Gregory, A.W. and B.E. Hansen, 1996, "Tests for Co-integration in Models with Regime and Trend Shifts", Oxford Bulletin of Economics and Statistics, 58, 555-560.

Greiner, L., 1972, "Evolutions and Revolutions as Organizations Grow", Harvard Business Review, 50, 37-46.

Gschwandtner, A., 2005, "Profit Persistence in the "Very" Long Run: Evidence from Survivors and Exiters", Applied Economics, 37, 793-806.

Hacker S. and A. Hatemi-J, 2006, "Test for Causality between Integrated Variables Using Asymptotic and Bootstrap Distributions: Theory and Application", Applied Economics, 38, 1489-1500.

Hacker S. and A. Hatemi-J, 2012, “A Bootstrap Test for Causality with Endogenous Lag Length Choice: Theory and Application in Finance", Journal of Economic Studies, 39, 144160.

Haines, W.W., 1970, "The Profitability of Large-Size Firms", Rivista Internazionale di Scienze Economiche e Commerciali, 17, 321-351.

Hall, M. and L.W. Weiss, 1967, "Firm Size and Profitability", The Review of Economics and Statistics, 49, 319-331.

Hatemi-J, A., 2003, “A New Method to Choose Optimal Lag Order in Stable and Unstable VAR Models", Applied Economics Letters, 10, 135-137.

Hatemi-J, A., 2008, "Tests for Co-integration with Two Unknown Regime Shifts with an Application to Financial Market Integration", Empirical Economics, 35, 497-505.

Hatemi-J, A., E. Roca and D. Buncic, 2006, "Bootstrap Causality Tests of the Relationship between the Equity Markets of the US and Other Developed Countries: Pre- and PostSeptember 11", Journal of Applied Business Research, 22, 65-74.

Huang, G. and F.M. Song, 2006, "The Determinants of Capital Structure: Evidence from China", China Economic Review, 17, 14-36.

Jang, S. and K. Park, 2011, "Inter-relationship between Firm Growth and Profitability", International Journal of Hospitality Management, 30, 1027-1035.

Johansen, S., 1991, "Estimation and Hypothesis Testing of Co-integration Vectors in Gaussian Vector Autoregressive Models", Econometrica, 59, 1551-1580.

Jonsson, B., 2007, "Does the Size Matter? The Relationship between Size and Profitability of Icelandic Firms", Bifröst Journal of Social Sciences, 1, 43-55.

Kaldor, N., 1966, Causes of Slow Rate of Economic Growth of the United Kingdom: An Inaugural Lecture, Cambridge University Press, Cambridge, UK. 
Khatab, H., M. Masood, K. Zaman, S. Saleem and B. Saeed, 2011, "Corporate Governance and Firm Performance: A Case Study of Karachi Stock Market", International Journal of Trade, Economics and Finance, 2, 39-43.

Kim, D. and P. Perron, 2009, "Unit Root Tests Allowing for a Break in the Trend Function at an Unknown Time under both The Null and Alternative Hypothesis", Journal of Econometrics, 148, 1-13.

Kwoka, J. and D. Ravenscraft, 1986, "Cooperation versus Rivalry: Price-Cost Margins by line of Business", Economica, 53, 351-364.

Li, H. and W. Wang, 2014, "Impact of Intangible Assets on Profitability of Hong Kong Listed Information Technology Companies", Business and Economic Research, 4, 98-113.

Liu, W.C. and C.M. Hsu, 2006, "Financial Structure, Corporate Finance and Growth of Taiwan's Manufacturing Firms", Review of Pasific Basin Financial Markets and Policies, 9, 67-95.

Maki, D., 2012, "Tests for Co-integration Allowing for an Unknown Number of Breaks", Economic Modelling, 29, 2011-2015.

Markham, G.D. and W.B. Gartner, 2002, "Is Extraordinary Growth Profitable? A Study of Inc. 500 High Growth Companies", Entrepreneurship Theory and Practice, 27, 65-75.

Mauri, A. and M. Michael, 1998, "Firm and Industry Effects within Strategic Management: An Empirical Examination", Strategic Management Journal, 19, 211-219.

McConnell, J.L., 1946, "Corporate Earnings by Size of Firm”, Survey of Current Business, 25, 6-12.

McGahan, A. and M. Porter, 1997, "How Much Does Industry Matter, Really?", Strategic Management Journal, 18, 15-30.

Mendelson, H., 2000, "Organizational Architecture and Success in the Information Technology Industry", Management Science, 46, 513-529.

Mueller, D., 1972, "A Life Cycle Theory of the Firm", The Journal of Industrial Economics, 20, 199-219.

Mule, R.K., M.S. Mukras and O.M. Nzioka, 2015, "Corporate Size, Profitability and Market Value: An Econometric Panel Analysis of Listed Firms in Kenya", European Scientific Journal, 11, 376-396.

Myers, S.C., 1984, “The Capital Structure Puzzle”, Journal of Finance, 39, 575-592.

Myers, S.C. and N.S. Majluf, 1984, "Corporate Financing and Investment Decisions When Firms Have Information That Investors Do Not Have", Journal of Financial Economics, 13, 187-221.

Nakano, A. and D. Kim, 2011, "Dynamics of Growth and Profitability: The Case of Japanese Manufacturing Firms", Global Economic Review: Perspectives on East Asian Economies and Industries, 40, 67-81. 
Narware, P.C., 2010, "Working Capital Management: The Effect of Market Valuation and Profitability in Malaysia", International Journal of Business and Management, 5, 140-147.

Ng, S. and P. Perron, 2001, "Lag Length Selection and the Construction of Unit Root Tests with Good Size and Power", Econometrica, 69, 1519-1554.

Özgülbaş, N., A.S. Koyuncugil and F. Yılmaz, 2006, "Identifying the Effect of Firm Size on Financial Performance of SMEs", The Business Review, 6, 162-167.

Padron, Y., G. Aplinario, O.M. Santana, M.C.V. Martel and L.J. Sales, 2005, “Determinant Factors of Leverage: An Empirical Analysis of Spanish Corporations", Journal of Risk Finance, 6, 60-68.

Perron, P. and S. Ng, 1998, "An Autoregressive Spectral Density Estimator at Frequency Zero for Nonstationarity Tests", Econometric Theory, 14, 560-603.

Perron, P. and Z. Qu, 2007, "A Simple Modification to Improve the Finite Sample Properties of Ng and Perron's Unit Root Tests", Economics Letters, 94, 12-19.

Perron, P. and G. Rodriguez, 2003, "GLS Detrending Efficient Unit Root Tests and Structural Change", Journal of Econometrics, 115, 1-27.

Rajan, R.G. and L. Zingales, 1995, "What do We Know about Capital Structure? Some Evidence from International Data", The Journal of Finance, 50, 1421-1460.

Reid, G.C., 1995, "Early Life-Cycle Behaviour of Micro-Firms in Scotland", Small Business Economics, 7, 89-95.

Robson, P.J.A. and R.J. Bennett, 2000, "SME Growth: The Relationship with Business Advice and External Collaboration", Small Business Economics, 15, 193-208.

Roper, S., 1999, "Modelling Small Business Growth and Profitability", Small Business Economics, 13, 235-252.

Roquebert, J., R. Phillips and P. Westfall, 1996, “Markets vs. Management: What "Drives" Profitability?", Strategic Management Journal, 17, 653-664.

Saliha, T. and A. Abdessatar, 2011, "The Determinants of Financial Performance: An Empirical Test Using the Simultaneous Equations Method", Economics and Finance Review, 10, 1-19.

Serrasquerio, Z.S., 2009, "Growth and Profitability in Portuguese Companies: A Dynamic Panel Data Approach", Economic Interferences, 11, 565-573.

Serrasquerio, Z.S. and P.M. Nunes, 2008, "Performance and Size: Empirical Evidence from Portuguese SMEs", Small Business Economics, 31, 195-217.

Serrasquerio, Z.S., P.M. Nunes and S.T.N. Sequeira, 2007, “Firms' Growth Opportunities and Profitability: A Nonlinear Relationship", Applied Financial Economics Letters, 3, 373379. 
Shepherd, D.A. and J. Wiklund, 2009, "Are We Comparing Apples with Apples or Apples with Oranges? Appropriateness of Knowledge Accumulation across Growth Studies", Entrepreneurship Theory \& Practice, 33, 105-123.

Shepherd, W.G., 1972, "The Elements of Market Structure", Review of Economics and Statistics, 54, 25-37.

Short, J.C., A. McKelvie, D.J. Ketchen and G.N. Chandler, 2009, "Firm and Industry Effects on Performance: A Generalization and Extension for New Ventures", Strategic Entrepreneurship Journal, 3, 47-65.

Sogorb, F. and J. Lopez, 2003, "Pecking Order versus Trade-off: An Empirical Approach to the Small and Medium Enterprise Capital Structure", Working Paper, Instituto Valenciano De Investigaciones Economicas, S.A.

Steffens, P., P. Davidsson and J. Fitzsimmons, 2009, "Performance Configurations over Time: Implications for Growth and Profit Oriented Strategies", Entrepreneurship Theory and Practice, 33, 125-148.

Stock, J.H. and M.W. Watson, 1993, "A Simple Estimator of Co-integrating Vectors in Higher Order Integrated Systems", Econometrica, 61, 783-820.

Stock, J.H., 1999, "A Class of Tests for Integration and Co-integration", in Co-integration, Causality, and Forecasting: A Festschrift for Clive W. J. Granger, Oxford University Press, 135-167.

Titman, S. and R. Wessels, 1988, "The Determinants of Capital Structure Choice", The Journal of Finance, 43, 1-19.

Toda, H.Y. and T. Yamamoto, 1995, "Statistical Inference in Vector Autoregressions with Possibly Integrated Processes", Journal of Econometrics, 66, 225-250.

Velnampy, T. and J.A. Niresh, 2012, "The Relationship between Capital Structure and Profitability", Global Journal of Management and Business Research, 12, 67-73.

Verdoorn, P., 1949, “Fattori Che Regolano lo Sviluppo Della Del Lavoro", L'Industria, 1, 310.

Vijayakumar, A. and S.S. Devi, 2011, "Growth and Profitability in Indian Automobile Firms An Analysis", Journal for Bloomers of Research, 3, 168-177.

Weinzimmer, L.G., P.C. Nystrom and S.J. Freeman, 1998, "Measuring Organizational Growth: Issues, Consequences and Guidelines", Journal of Management, 24, 235-262.

Westerlund, J. and D.L. Edgerton, 2007, "A Panel Bootstrap Co-integration Tests", Economics Letters, 97, 185-190.

Wiwattanakantang, Y., 1999, "An Empirical Study on the Determinants of the Capital Structure of the Thai Firms", Pacific-Basin Finance Journal, 7, 371-403.

Wu, M.L., 2006, “Corporate Social Performance, Corporate Financial Performance, and Firm Size: A Meta- Analysis", Journal of American Academy of Business, 8, 163-172. 
Zeitun, R. and G. Tian, 2007, “Capital Structure and Corporate Performance: Evidence from Jordan", The Australasian Accounting Business \& Finance Journal, 1, 40-61.

Zivot, E. and D.W.K. Andrews, 1992, "Further Evidence on the Great Crash, the Oil Price Shock, and the Unit-Root Hypothesis", Journal of Business \& Economic Studies, 10, 251270. 